\title{
Correction to: Liming in spruce stands: What effect does the number of lime applications have on the herb layer?
}

\author{
Martin Baumann ${ }^{1} \cdot$ Sebastian Dittrich ${ }^{2}$ (I) $\cdot$ Michael Körner $^{3} \cdot$ Goddert von Oheimb ${ }^{2,4}([)$
}

Published online: 18 May 2019

○) Springer-Verlag GmbH Germany, part of Springer Nature 2019

Correction to: European Journal of Forest Research https://doi.org/10.1007/s10342-019-01191-5

In the original publication of the article, the 8th column heading in Table 2 that reads as "L6" should read as "SB". Goddert von Oheimb's ORCID iD was missing in the original publication and it is included in this correction.

Publisher's Note Springer Nature remains neutral with regard to jurisdictional claims in published maps and institutional affiliations.

The original article can be found online at https://doi.org/10.1007/ s10342-019-01191-5.

Sebastian Dittrich

Sebastian.dittrich@tu-dresden.de

1 Public Enterprise Sachsenforst, Competence Centre for Wood and Forestry, Bonnewitzer Str. 34, 01796 Pirna, Germany

2 Institute of General Ecology and Environmental Protection, Technische Universität Dresden, Pienner Str. 7, 01737 Tharandt, Germany

3 Faculty of Forest and Environment, Eberswalde University for Sustainable Development, Alfred-Möller-Str. 1, 16225 Eberswalde, Germany

4 German Centre of Integrative Biodiversity Research (iDiv) Halle-Jena-Leipzig, Deutscher Platz 5E, 04103 Leipzig, Germany 